\title{
IKLAN TOKOPEDIA VERSI BTS SEBAGAI REPRESENTASI KOREAN WAVES
}

\author{
Adrian Conita ${ }^{1}$, Yulianto Hadiprawiro ${ }^{2}$, Atiek Nur Hidayati ${ }^{3}$ \\ Universitas Nasional ${ }^{1}$, Universitas Indraprasta PGRI ${ }^{23}$ \\ Corresponding author: Adrian Conita, adrianconita@gmail.com, Jakarta, Indonesia
}

\begin{abstract}
Abstrak. Perkembangan zaman yang pesat membuat teknologi mengalami banyak perubahan dari waktu ke waktu. Kemajuan teknologi ini ditandai dengan munculnya internet dimana saat ini semua orang dapat menggunakan internet untuk berbagai keperluan. Saat ini belanja online sudah menjadi kebutuhan pokok di semua kalangan. Perusahaan e-commerce bersaing satu sama lain untuk menarik perhatian orang dengan membuat iklan yang menggunakan duta merek (Brand Ambassador). Tokopedia merupakan mall online yang memungkinkan penjual untuk membuka toko dan melakukan penjualan dengan mudah tanpa harus memikirkan sewa toko dan membayar gaji karyawan dengan mengutamakan keamanan transaksi, menawarkan pengalaman jual beli online yang aman, mudah dan nyaman. Tujuan dari penelitian ini adalah untuk menganalisis representasi Gelombang Korea yang tercermin dari keberadaan BTS dalam Iklan Komersial Tokopedia. Dalam penelitian ini menggunakan metode analisis semiotik Charles Sanders Pierce dengan pendekatan kualitatif. Hasil penelitian ini menunjukkan bahwa representasi Korean Waves melalui BTS sebagai brand ambassador Tokopedia dalam iklan YouTube tercermin dari karakter positif sosok individu atau kelompok yang muncul untuk menarik persona konsumen Tokopedia.
\end{abstract}

Kata kunci: Korean Waves, Brand Ambassador, citra persona

\begin{abstract}
The rapid development of times has made technology have many changes from time to time. This technological advancement is marked by the emergence of an internet where now everyone can use the internet for various purposes. Nowadays online shopping has become a basic necessity in all circles. E-commerce companies compete with each other to attract people's attention by creating advertisements using brand ambassadors. Tokopedia is an online mall that allows sellers to open stores and make sales easily without having to think about renting a shop and paying employee salaries by prioritizing transaction security, offering a safe, easy and convenient online buying and selling experience. The purpose of this study was to analyze the Korean Waves representation that reflected from the presence of BTS in Tokopedia Commercial Ads. In this study, using Charles Sanders Pierce's semiotic analysis method with a qualitative approach. The results of this study indicate that the Koren Waves representation through BTS as the Tokopedia brand ambassador in YouTube advertisements is reflected in the positive character of the individual or group figures that appear to attract Tokopedia's consumer persona.
\end{abstract}

Keywords: Korean Waves, Brand Ambassador, persona image

\section{Pendahuluan}

Di Tahun 2000-an, pasar Asia masih didominasi produk budaya dari luar negeri, seperti Amerika Serikat, Jepang dan Cina. Namun, saat itu, Pemerintah Korea Selatan mencoba mengekspor produk budaya bersama dengan elektronik dan produk makanan. Seiring 
berjalannya waktu, budaya Korea Selatan produk menjadi terkenal dan lebih populer dari sebelumnya. Produk budaya mereka meliputi film, drama, dan musik pop, fenomena yang disebut 'Gelombang Korea'. Musik dan industri film di Korea Selatan adalah faktor utama itu memperkenalkan Korean Wave sendiri. Drama dan film Korea selalu membawa unsur budaya, misalnya fashion, makanan, atau area lain di Korea Selatan (Tjoe and Kim 2016, 66).

Beberapa penelitian cenderung menunjukkan bahwa penggunaan brand ambassador memiliki efek paling positif. Sagala dan Mulyaningsih dalam Gultom and Sari $(2019,4049)$ menyatakan bahwa brand ambassador akan membantu membuat hubungan emosional yang lebih kuat antara sebuah brand atau perusahaan dengan konsumen yang mana secara tidak langsung akan membangun citra brand. Menunjuk artis sebagai duta brand akan memengaruhi citra perusahaan. Sama seperti Tokopedia yang mengangkat BTS sebagai brand ambassador, mereka akan mendapat perhatian dari Fans BTS, loyalitas sebagai fans dan menggunakan produk yang di-endorse oleh idol tersebut (Tina and Utami 2020, 676).

Dalam tema hubungan kebijakan pemerintah Korea berhubungan dengan industri di dunia. Untuk strategi ekonomi budaya, pemerintahnya menerapkan kebijakan yang kontradiktif untuk industri budaya, yang ramah bisnis dan neoliberal di satu sisi dan perkembangan dan intervensi negara di sisi lain. Sedangkan untuk strategi politik budaya, pemerintah memanfaatkan yang Baru Gelombang Korea untuk mengumpulkan faksi kekuatan yang berbeda, masing-masing memiliki kepentingan yang berbeda dalam proyek hegemonik, tetapi baik mengadvokasi untuk meningkatkan kepentingan nasional dan mempromosikan " brand nasional". Dalam proses ini, pemerintah mengerahkan berbagai sumber daya seperti anggaran nasional, organ administrasi, undang-undang, dan institusi publik, sehingga memproduksi dan memperkuat Hallyu sebagai kekuatan simbolik negara (Jeong, Lee, and Lee 2017, 2290). Penelitian yang lain membahas tentang respon masyarakat Indonesia dan Malaysia terhadap Korean Waves, menyatakan bahwa kata-kata bersama antara kedua negara ini dan kata-kata unik dari setiap negara yang terkait dengan produk budaya yang sama menyoroti pentingnya memahami perbedaan di setiap negara latar belakang etnis, sosial ekonomi, dan sejarah ketika meneliti hibriditas budaya antara Korean waves dan budaya Muslim (Lee et al. 2020).

Pada saat ini teknologi yang terus menerus berkembang pesat sangat memudahkan manusia untuk melakukan aktivitas kesehariannya dalam berbagai bidang. Salah satunya bidang yang saat ini paling banyak diminati adalah e-bussines. Bisnis online banyak diminati dengan alasan karena modal yang kecil dengan keuntungan yang lumayan besar dan memiliki jangkauan yang luas. Dengan adanya beberapa aplikasi berjualan online yang saat ini sangat beragam fungsinya dengan berbagai macam nama yang dibangun dari perusahaan masing-masing, maka dari sekian banyak aplikasi tersebut akan membuat para calon penjual online dan pembeli memilih aplikasi mana yang lebih diminati.

Belanja online telah menjadi sebuah kebutuhan dasar di semua kalangan, sehingga sangat menciptakan peluang yang cukup besar bagi perusahaan e-commerce. Perusahaan e-commerce akan bersaing satu sama lain yang memiliki tujuan untuk menarik perhatian masyarakat kemudian menguasai pangsa pasar. Maka dengan demikian perusahaan terus menciptakan strategi untuk mampu bertahan. Ada berbagai macam cara yang tepat untuk menarik perhatian masyarakat adalah salah satunya dengan menggunakan brand ambassador. Harapan perusahaan yang menggunakan brand ambassador yaitu untuk membangun brand awareness atau kesadaran brand suatu produk yang diwakilkan oleh celebrity yang bersangkutan agar mudah teringat di benak masyarakat.

Salah satu perusahaan e-commerce yang menggunakan brand ambassador adalah Tokopedia. Tokopedia adalah marketplace atau mall online terbesar di Indonesia yang bisa digunakan oleh individu maupun pemilik usaha di Indonesia untuk membuka dan mengelola toko online mereka dengan cara yang mudah dan gratis, serta memberikan pengalaman berbelanja online yang lebih aman dan nyaman bagi masyrakat. Tokopedia merupakan salah 
satu perusahaan yang menggunakan beberapa media dalam mempromosikan website mereka. Perusahaan jual-beli online ini menggunakan iklan yang beragam dalam mempromosikan aplikasi mereka, salah satunya iklan Tokopedia yang ada di YouTube.

Sementara sebagai perbandingan e-commerce selain Tokopedia, juga ada Shopee yang memakai BlackPink sebagai brand ambassadornya. Hal ini menunjukkan bahwa brand image dari e-commerce Shopee sudak baik di mata konsumen di antaranya persepsi yang baik mengenai e-commerce Shopee, Shopee merupakan e-commerce terkenal, pelayanan yang diberikan sesuai dengan yang diharapkan serta produk yang dicari dapat ditemukan dengan mudah di e-commerce Shopee (Gultom and Sari 2019, 4049).

Mengetahui siapa pelanggan ideal dan siapa yang harus membeli layanan/ produk yang diberikan adalah pokok dari setiap strategi pemasaran. Definisi persona pembeli adalah salah satu langkah penting pertama untuk membuat keputusan dan investasi bisnis, produk, dan pemasaran yang lebih baik. Perusahaan sebagai brand disarankan untuk meluangkan waktu untuk mengadopsi pendekatan berbasis data untuk membuat profil persona pembeli untuk menerapkan praktik pemasaran yang lebih strategis dan bertarget.

Berdasarkan data yang telah didapatkan dari We Are Social, Hootsuite 2020, bahwa penggunaan media sosial yang sering digunakan oleh masyarakat Indonesia yaitu YouTube, WhatsApp, Facebook, dan Instagram yang telah menjadi empat besar media sosial. Persentase pengguna yang mengakses YouTube mencapai $88 \%$ sehingga menjadi urutan nomor satu yang paling sering digunakan oleh penduduk Indonesia dimulai dari usia 16 hingga 64 tahun dan ratarata waktu yang dihabiskan masyarakat Indonesia untuk mengakses sosial media selama 3 jam 26 menit dengan menggunakan ponsel (Jayani 2020).

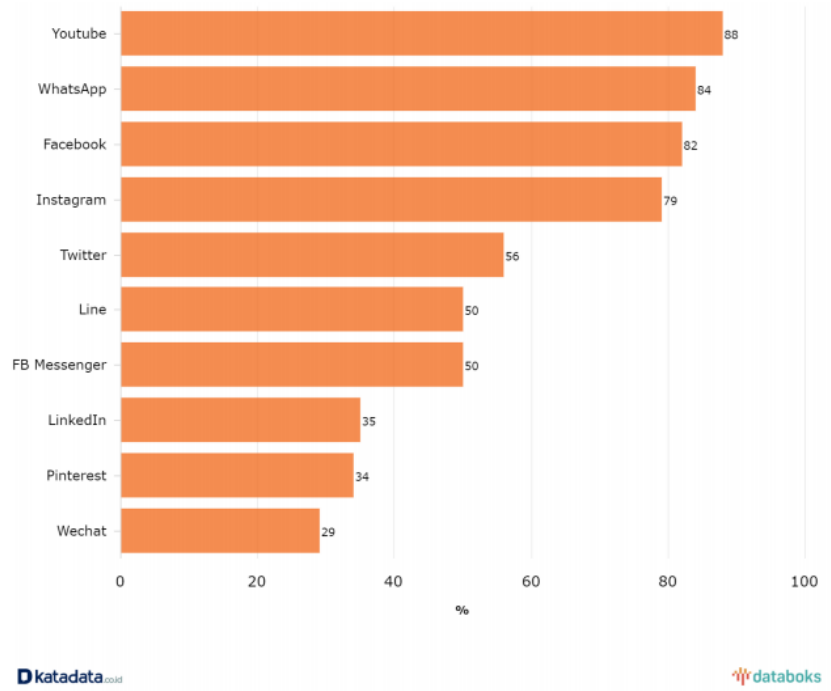

Gambar 1 Data Media Sosial Yang Sering Digunakan pada Tahun 2020.

Sumber: (Jayani 2020)

Tokopedia kembali mempertahankan sebagai e-commerce dengan pengunjung paling banyak pada triwulan III 2018. Berdasarkan hasil riset iprice jumlah pengunjung salah satu Unicorn asal Indonesia ini mencapai 153,64 juta. Angka tersebut mengalahkan pengunjung ecommerce lainnya seperti Bukalapak, Shopee maupun Lazada. Pada triwulan sebelumnya Tokopedia juga mencatat jumlah pengunjung terbanyak, yakni mencapai 111,48 juta.

Salah satu penopang tingginya pengunjung Tokopedia berasal dari Facebook, yakni mencapai 5,89 juta. Kemudian diikuti Instagram sebanyak 903 ribu pengunjung dan Twitter 174 ribu pengunjung. Ini mengindikasikan bahwa peran media sosial terhadap penetrasi kunjungan e-commerce cukup penting. Aplikasi perdagangan elektronik tersebut telah diunduh 
sekitar 10 juta kali. Jumlah populasi yang mencapai 266 juta jiwa serta wilayah yang berbentuk kepulauan membuat Indonesia merupakan pangsa pasar yang cukup menggiurkan. Ini yang menjadi alasan e-commerce global tertarik untuk menyasar pasar online lokal. Berdasarkan data internetworldstats, penetrasi internet Indonesia mencapai 53,7\% dari total populasi. Sementara jumlah pengguna Facebook mencapai 130 juta.

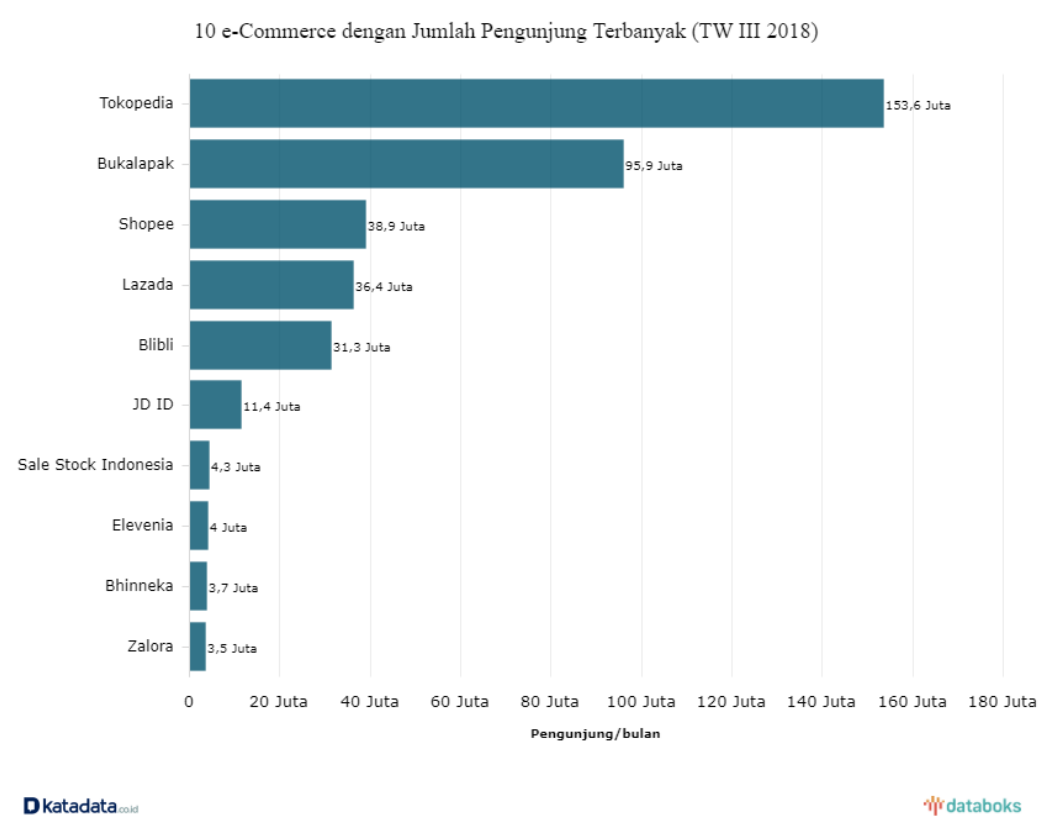

Gambar 2 Data e-commerce dengan jumlah pengunjung terbanyak, 2018.

Sumber: (Databoks 2018)

\section{Metode}

Pendekatan penelitian yang digunakan oleh penulis dalam penelitian ini adalah pendekatan kualitatif. Menurut Bogdan dan Taylor dalam Moleong $(2018,4)$ "Metode penelitian kualitatif adalah sebagai prosedur penelitian yang menghasilkan data deskriptif berupa katakata tertulis atau lisan dari orang-orang dan perilaku yang bisa diamati. Dalam penelitian kualitatif peneliti sendiri atau dengan bantuan orang lain adalah alat pengumpul data utama. Segala temuan data di lapangan akan disusun menggunakan metode tertentu dan berdasarkan data yang terkumpul akan digambarkan secara deskriptif, tanpa mengurangi kevalidan yang diperoleh dalam proses analisisnya.

Peneliti menggunakan metode analisis semiotika Charles Sanders Pierce dengan pendekatan kualitatif. Semiotik adalah ilmu tentang tanda-tanda. Studi tentang tanda dan segala yang berhubungan dengannya, cara berfungsinya, hubungannya dengan tanda-tanda lain, pengirimannya dan penerimaannya oleh mereka yang menggunakannya (Kriyantono 2006, 265). Dalam analisis semiotika Pierce ini, penulis menganalisis teori segi tiga makna (triangle meaning) yang terdiri atas tanda (sign), objek (object), dan interpretan (interpretant). Peneliti memilih model Pierce ini agar dapat mengetahui studi tentang bagaimana representasi BTS sebagai brand ambassador Tokopedia dalam iklan YouTube.

Menurut Arikunto $(2016,26)$, objek penelitian adalah variabel penelitian yaitu hal yang merupakan inti dari problematika penelitian. Adapun objek penelitian yang dijadikan sumber dalam penelitian ini adalah iklan Tokopedia versi BTS sebagai brand ambassador dalam 
YouTube. Sedangkan subjek penelitian menurut anggota batasan subjek penelitian sebagai benda, hal atau orang tempat data untuk variable penelitian melekat, dan yang dipermasalahkan. Adapun subjek penelitian yang dijadikan sumber dalam penelitian ini adalah anggota grup band BTS yang terdiri dari 7 orang. Informan pada penelitian ini adalah penggemar BTS, pengguna Tokopedia, pengguna YouTube.

Teknik pengumpulan data yang digunakan oleh peneliti untuk memperoleh informasi maupun data yang terkait dengan topik penelitian adalah sebagai berikut: wawancara dilakukan kepada penggemar BTS, pengguna Tokopedia, dan pengguna YouTube sebagai informasi pendukung. Iklan Tokopedia dalam Youtube dipilah berdasarkan elemen visual berupa tampilan figur anggota BTS dan copywriting berupa teks verbal vokal atau non-vokal yang ada, kemudian dianalisis menggunakan semiotika Charles Sanders Pierce.

Setelah data primer dan data sekunder terkumpul, kemudian diklarifikasikan sesuai dengan pertanyaan penelitian yang telah ditentukan. Setelah data terklarifikasi, dilakukan analisis data dengan menggunakan teknik analisis semiotika Charles Sanders Pierce. Pierce mengembangkan teori segi tiga makna (triangle meaning) yang terdiri atas tanda (sign), objek (object), dan interpretan (interpretant). Menurut Pierce salah satu bentuk tanda adalah kata, sedangkan objek adalah sesuatu yang dirujuk tanda. Sementara interpretan adalah tanda yang ada dalam benak seseorang tentang objek yang dirujuk sebuah tanda (Sobur 2006, 114-115). Dalam hal ini, figur anggota BTS sebagai Brand Ambassador Tokopedia dianggap sebagai tanda, iklan Tokopedia dianggap sebagai objek yang merujuk pada tanda, dan respon pengguna Tokopedia, pengguna Youtube, penggemar BTS terhadap iklan Tokopedia tersebut dianggap sebagai interpretannya.

\section{Hasil dan Pembahasan}

\section{tokopedia}

Gambar 3 Logo Tokopedia.

Sumber: (Tokopedia)

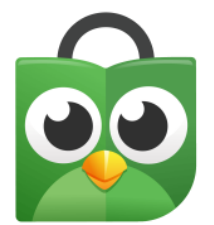

Gambar 4 Maskot Tokopedia.

Sumber: (Tokopedia)

Tokopedia berasal dari kata Toko dan Ensiklopedia. Dan juga maskot Tokopedia merupakan percampuran dari burung hantu dengan kantong belanja. Arti burung hantu memiliki karakter yang cerdas dan burung hantu memiliki bentuk kepala yang bisa memutar $360^{\circ}$ atau dapat melihat kesegala arah, yang berarti Tokopedia ingin menjadi marketplace yang tidak memihak kepada siapapun dan bisa melihat permasalahan dan menengahinya secara adil dari segala aspek dan pihak. Arti kantong belanja karena harapan Tokopedia bisa menjadi one stop solution shopping untuk Toppers (Tokopedia 2015).

Tokopedia dengan nama resmi PT Tokopedia merupakan startup di bidang perdagangan elektronik yang didirikan pada 6 Februari 2009 dan resmi diluncurkan ke publik pada 17 Agustus 
2009. Memiliki visi membangun sebuah Super Ecosystem dimana siapapun bisa memulai dan menemukan apa pun serta memiliki misi untuk mencapai pemerataan ekonomi secara digital. Tokopedia diciptakan oleh William Tanuwijaya dan Leontinus Alpha Edison. William Tanuwijaya yang menjabat sebagai Co-Founder dan CEO. PT. Tokopedia mendapatkan seed funding (pendanaan awal) dari PT Indonusa Dwitama pada tahun 2009, suntikan dana dari pemodal ventura global seperti East Ventures pada tahun 2010, Cyber Agent Ventures pada tahun 2011, Netprice pada tahun 2012 dan Soft Bank Ventures pada tahun 2013. Pada Oktober tahun 2014, Tokopedia berhasil mencetak sejarah sebagai perusahaan teknologi pertama di Asia Tenggara dengan menerima investasi sebesar 100 juta USD atau sekitar Rp. 1,2 triliun dari Squoia Capital dan Softbank Internet dan Media Inc (SIMI). Kemudian Tokopedia kembali dikabarkan mendapatkan investasi sebesar 147 jutaUSD atau sekitar Rp 1,9 triliun (Onlenpedia 2015).

Alasan yang mendasari William Tanuwijaya dan Leontinus Alpha Edison mendirikan Tokopedia karena menghadapi pengalaman hidup dan tantangan yang serupa. Mereka berpikir untuk menghentikan permasalahan ini, mereka harus melakukan sesuatu untuk memperpendek jurang pemisah antara kota besar dan kota kecil. Hal lain yang mendasari berdirinya Tokopedia adalah turut mendukung para pelaku Usaha Mikro Kecil dan Menengah (UMKM) dan perorangan untuk mengembangkan usaha mereka dengan memasarkan produk secara daring dengan berjualan dan membuka toko di Tokopedia secara gratis (Tokopedia).

Sejak resmi diluncurkan, PT Tokopedia berhasil menjadi salah satu perusahaan internet Indonesia dengan pertumbuhan yang sangat pesat. Berkat peranannya dalam mengembangkan bisnis daring di Indonesia, Tokopedia berhasil meraih penghargaan Marketeers of the Year 2014 untuk sektor E-Commerce pada acara Markplus Conference 2015 yang digelar oleh Markplus Inc tanggal 11 Desember 2014. Pada tanggal 12 Mei 2016, Tokopedia terpilih sebagai Best Company in Consumer Industry dari Indonesia Digital Economy Award 2016. Dan pada tahun 2018 aplikasi Tokopedia berhasil memuncaki Apple Store mengalahkan Facebook, WhatsApp, dan Instagram. Sementara di Android, Tokopedia juga berhasil menjadi \#3 Top Chart di Google Play mengalahkan Facebook dan Instagram. Pada Desember 2018 Tokopedia terpilih sebagai aplikasi terbaik pilihan masyarakat di Google Play (TribunWiki 2019).

Tokopedia memiliki berbagai macam kegunaan bagi penggunanya, terdapat beberapa macam kategori yaitu untuk jual-beli, Top-up (pulsa, paket data, pascabayar, Telkom, zakat, donasi, Ovo, dII), untuk bayar tagihan (listrik PLN, BPJS, TV Kabel, angsuran kredit, premi asuransi), untuk travel (tiket kereta api, tiket pesawat, dan hotel), untuk entertainment (tiket event, hiburan, deals, M-Tix XXI, streaming, voucher game, vouchers), untuk keuangan (kredit motor, Reksa Dana, Ovo PayLater, pinjaman online, pinjaman modal, Home Credit, Kredivo, dII), untuk belanja (elektronik, fashion, rumah tangga, mainan, kesehatan, kecantikan, souvenir dan kado, aksesoris, buku, gaming, film dan musik). Hampir semua yang dijual di toko offline dapat dengan mudah dijual di situs Tokopedia. Hal ini sangat memudahkan para pembeli yang tidak mempunyai waktu untuk berbelanja di toko online karena jam kerja yang cukup menyita waktu.

Tokopedia dilengkapi dengan mesin pencari (search engine) yang akan memudahkan pencarian barang yang diinginkan dan terdapat juga fitur-fitur direktori yang dapat dimanfaatkan sebagai katalog belanja. Tokopedia bekerjasama dengan agen pengiriman besar di Indonesia yang mempermudah untuk memeriksa status pengiriman barang. Tokopedia juga menjelaskan di situs mereka bahwa keuntungan bagi pembeli dengan pembayaran yang unik adalah proses verifikasi pembayaran yang instan, yang memungkinkan penjual lebih cepat menerima order dan barang cepat sampai ke pembeli. Sedangkan untuk penjual, keuntungan yang ditawarkan adalah perluasan pasar pada para pengguna untuk yang ingin membeli di berbagai merchant Tokopedia. Beberapa fitur-fitur tambahan di Tokopedia yaitu (Herdadi 2019): 


\section{JNE Online Booking}

Dengan menggunakan pengiriman JNE akan memudahkan proses pengiriman, Tokopedia mendukung sistem resi otomatis untuk pengiriman paket menggunakan JNE. Dengan fitur ini, penjual tidak perlu repot untuk memasukkan nomor resi secara manual. Saat mengirimkan pesanan, penjual hanya perlu membawa kode booking yang diterima saat pesanan masuk dan nomor resi akan secara otomatis masuk ke akun penjual maupun pembeli.

2. User Management/Pengaturan Admin

Pengaturan admin merupakan fitur berbayar yang disediakana oleh Tokopedia bagi mereka yang memiliki toko dengan penjualan yang tinggi dan sering kewalahan dalam mengelola toko sendiri. Dengan menggunakan fitur ini, penjual bisa menambahkan 10 orang sebagai admin toko penjual.

\section{Tokopedia TopAds}

Top Ads adalah fitur yang ditawarkan oleh tokopedia untuk mempromosikan toko ataupun produk dari toko, serta membuat toko dan produk yang dijual dapat dilihat dan dibeli oleh lebih banyak pembeli di Tokopedia.

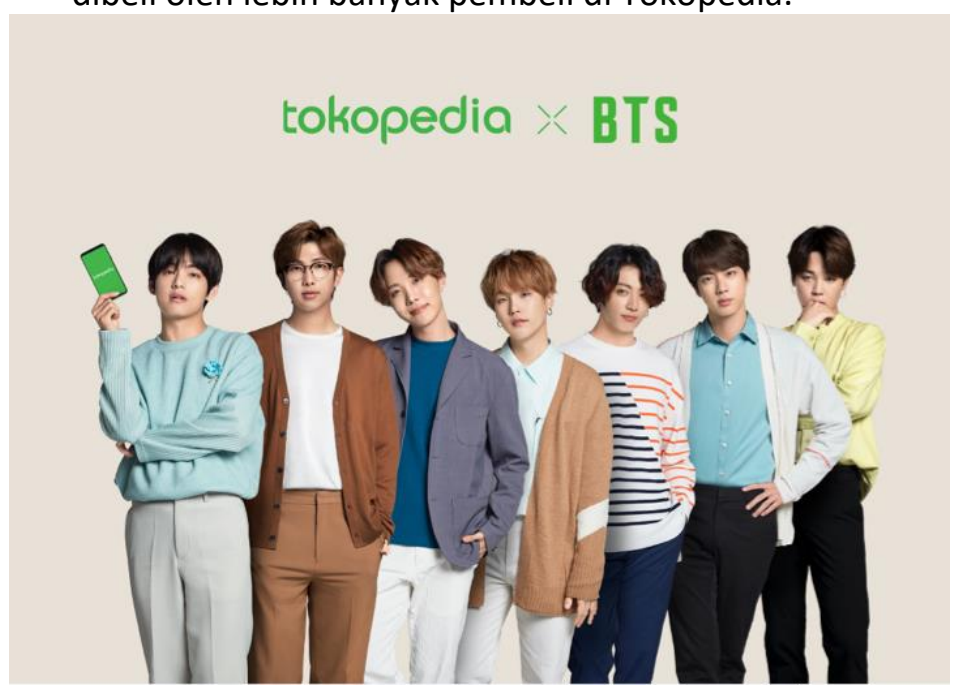

Gambar 5 Tokopedia x BTS

Sumber: (Tokopedia)

Pada 7 Oktober 2019, Tokopedia melalui akun YouTube-nya pada gambar di atas resmi menggandeng Boyband asal Korea Selatan yaitu BTS. Berdasarkan press release dari website resmi Tokopedia, William Tanuwijaya selaku Co-Founder dan CEO Tokopedia menyatakan bahwa perjalanan dan visi BTS selaras dengan visi Tokopedia serta pesan-pesan yang secara konsisten BTS sampaikan sehingga BTS merupakan mitra yang tepat untuk menyampaikan pesan Tokopedia kepada seluruh dunia.

Kerjasama yang dilakukan antara Tokopedia dan BTS tidak hanya sebatas menjadikan BTS sebagai brand ambassador pada iklan, bahwa Tokopedia juga menyediakan official store resmi dari Tokopedia yang menjual merchandise dari BTS secara ekslusif yang bertujuan agar memudahkan para fans yang dikenal dengan sebutan Army, untuk mengoleksi barang-barang yang berkaitan dengan BTS seperti pada gambar di bawah ini: 


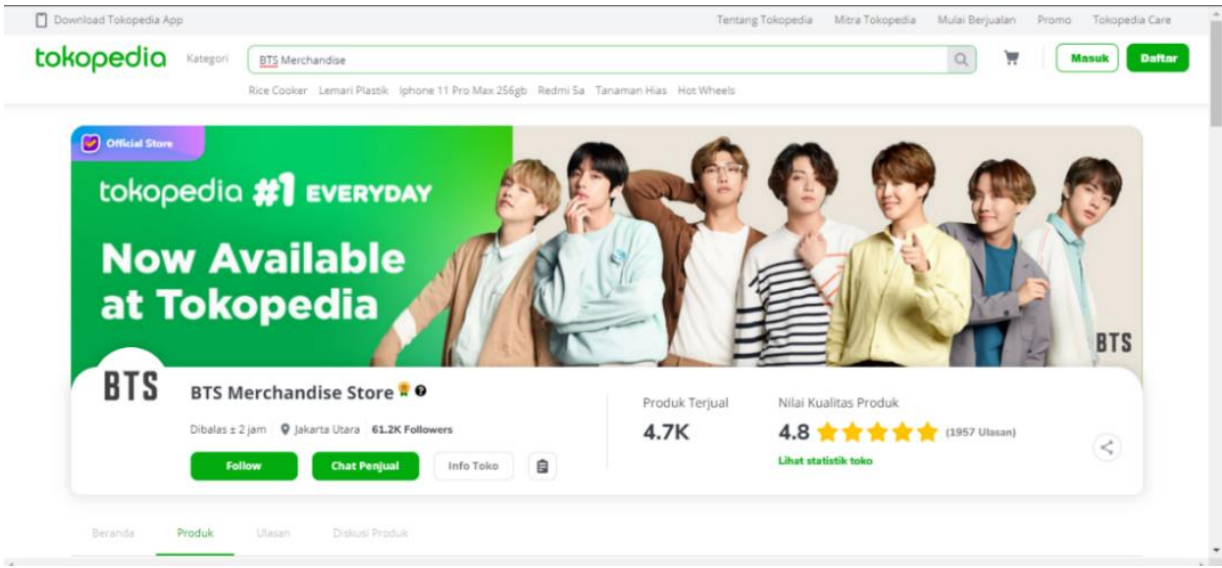

Gambar 6 BTS Merchandise Official Store Tokopedia.

Sumber: https://www.tokopedia.com/btsmerchandise

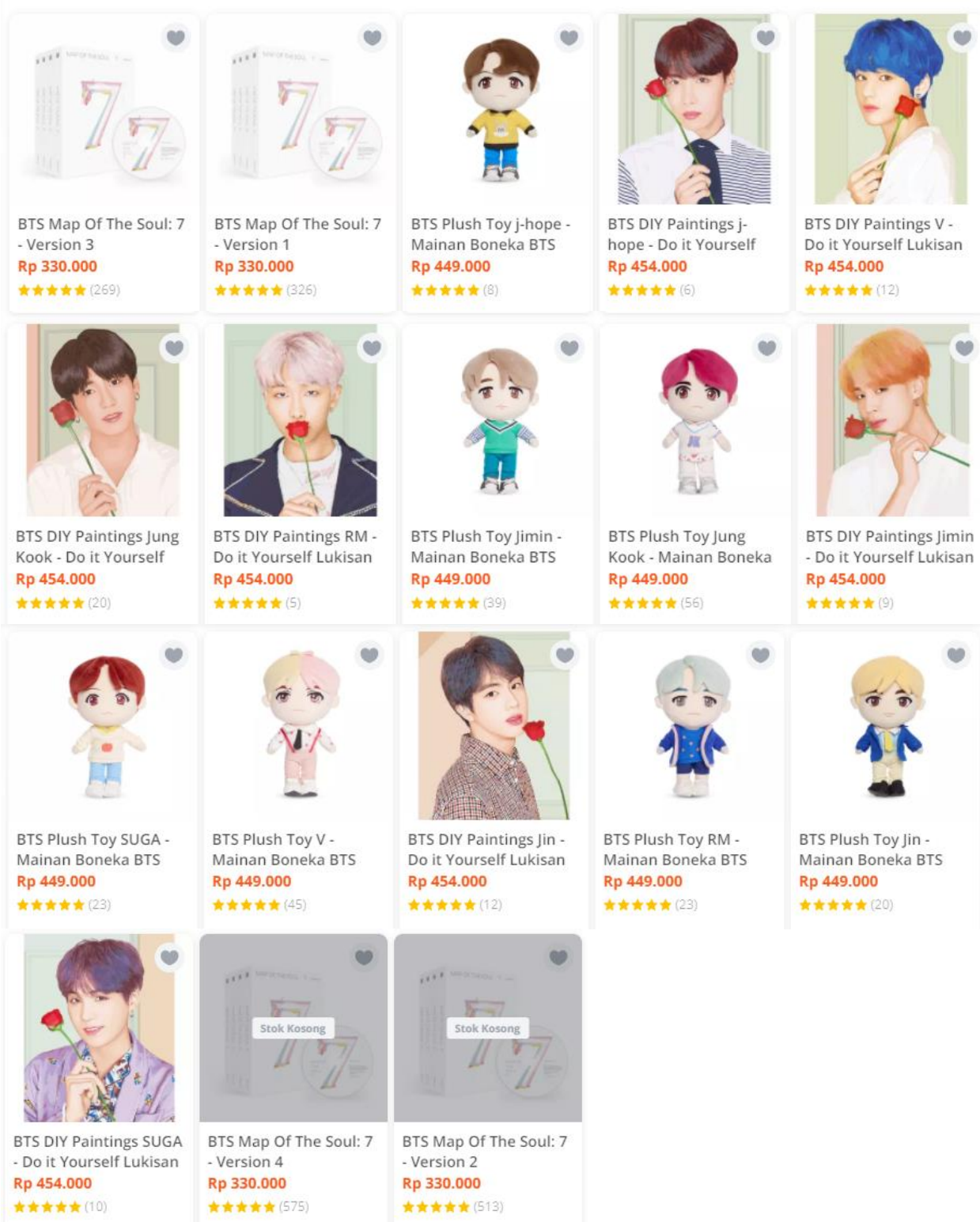

Gambar 7 Katalog BTS Merchandise Store Tokopedia.

Sumber: https://www.tokopedia.com/btsmerchandise 
BTS singkatan dari Bangtan Sonyeondan atau "Beyond the Scene", adalah boyband Korea Selatan yang telah merebut hati jutaan penggemar di seluruh dunia sejak debut mereka pada Juni 2013. Anggota BTS adalah RM, Jin, SUGA, j- hope, Jimin, $V$ dan Jung Kook. BTS telah memperoleh pengakuan dari musik asli yang diproduksi sendiri dan pertunjukan terbaik hingga cara mereka berinteraksi dengan penggemar, band ini telah memantapkan diri mereka sebagai superstar global yang memecahkan rekor dunia yang tak terhitung jumlahnya. BTS telah anggotaikan pengaruh positif melalui kegiatan seperti kampanye LOVE MYSELF dan pidato PBB 'Speak Yourself', BTS telah memobilisasi jutaan penggemar di seluruh dunia bernama ARMY, menduduki puncak tangga musik terkemuka, menjual tur di seluruh dunia termasuk stadion dan telah dinobatkan sebagai salah satu dari TIME 100: The Most Influential People of 2019. Band ini juga telah diakui dengan berbagai penghargaan bergengsi seperti Billboard Music Awards dan American Music Awards (ibighit).

Berikut di bawah ini adalah biodata dari seluruh anggota BTS:

Tabel 1 Biodata anggota Boyband BTS

\begin{tabular}{|c|c|c|}
\hline No. & FOTO PROFIL BTS & BIODATA ANGGOTA \\
\hline 1. & & $\begin{array}{ll}\text { Real Name } & \text { : Kim Nam Joon / RM BTS } \\
\text { Position } & : \text { Leader \& Main Rapper } \\
\text { Date of Birth } & \text { : llsan, Gyeonggi-Do. 12th September, } 1994 . \\
\text { Zodiac } & : \text { Virgo } \\
\text { Height \& Weight } & \text { : } 181 \mathrm{~cm} \& 67 \mathrm{~kg} \\
\text { Hobbies } & : \text { Berselancar di dunia maya }\end{array}$ \\
\hline 2. & & $\begin{array}{ll}\text { Real Name } & \text { : Kim Seok Jin / Jin BTS } \\
\text { Position } & : \text { Vocalist \& Visual } \\
\text { Date of Birth } & \text { : Anyang. 4th December, } 1992 . \\
\text { Zodiac } & : \text { Sagitarius } \\
\text { Height \& Weight } & \text { : } 179 \mathrm{~cm} \& 63 \mathrm{~kg} \\
\text { Hobbies } & : \text { Memasak, bermain video game, mengambil } \\
& \text { foto selfie }\end{array}$ \\
\hline 3. & & $\begin{array}{ll}\text { Real Name } & \text { : Min Yoon Gi / SUGA BTS } \\
\text { Position } & \text { : Lead Rapper } \\
\text { Date of Birth } & \text { : Daegu 9th March, } 1993 . \\
\text { Zodiac } & \text { : Pisces } \\
\text { Height \& Weight } & : 174 \mathrm{~cm} \& 59 \mathrm{~kg} \\
\text { Hobbie } & : \text { Berfoto, bermalas-malasan saat waktu } \\
& \text { luang }\end{array}$ \\
\hline 4. & & $\begin{array}{ll}\text { Real Name } & \text { : Jung Ho Seok / J-Hope BTS } \\
\text { Position } & \text { : Main Dancer, Rapper, Sub Vocalist } \\
\text { Date of Birth } & : \text { Gwangju 18th February, 1994. } \\
\text { Zodiac } & \text { : Aquarius } \\
\text { Height \& Weight }: & 177 \mathrm{~cm} \& 65 \mathrm{~kg} \\
\text { Hobbies } & \text { : Mendengarkan musik }\end{array}$ \\
\hline
\end{tabular}




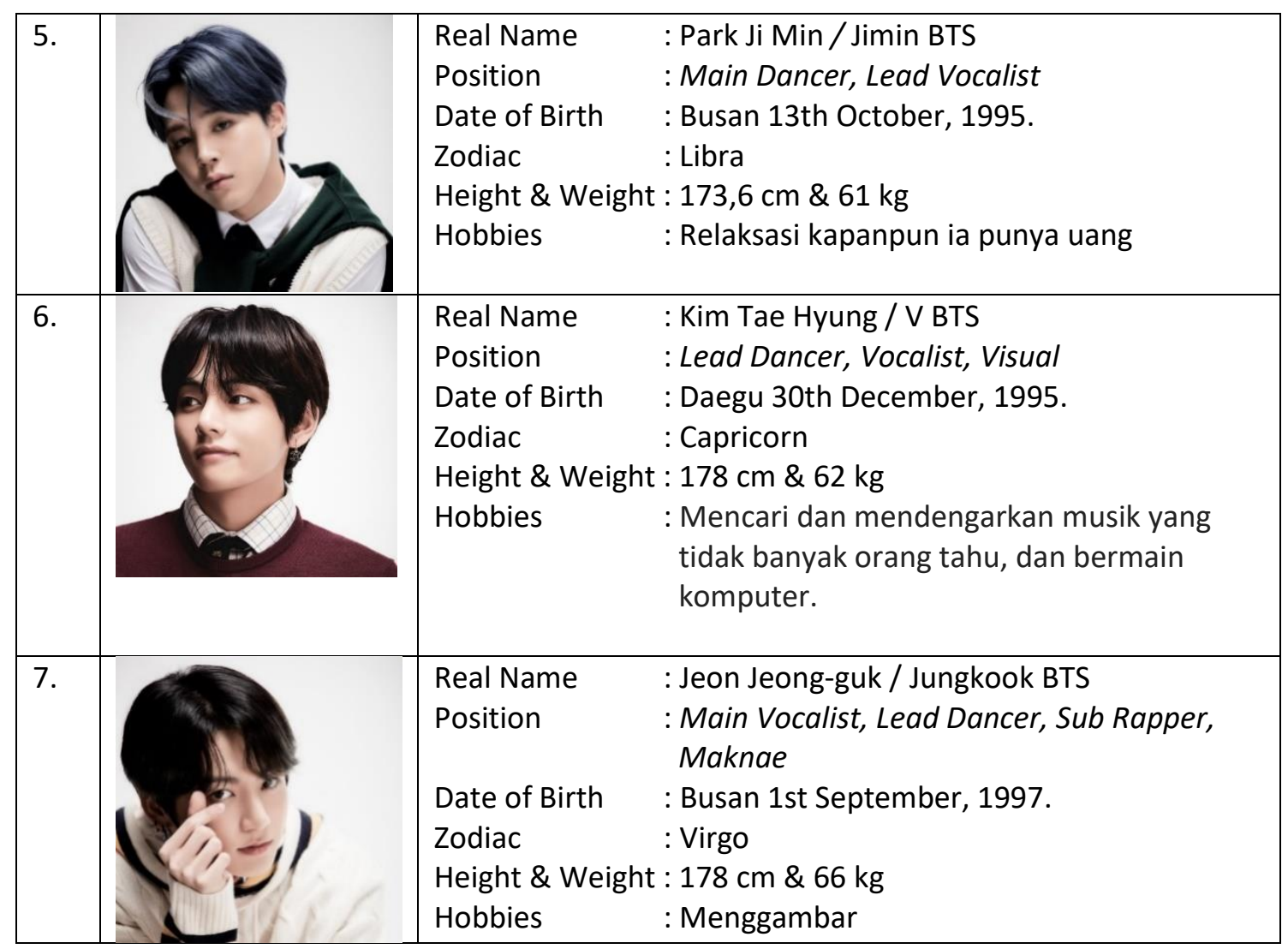

Sumber: (Tokopedia 2021)

\section{Pembahasan}

Dalam penelitian ini, teori milik Charles Sanders Pierce menjadi pisau untuk menganalisis representasi BTS sebagai brand ambassador Tokopedia. Pierce, secara khusus anggotai perhatian pada tanda dan objek yang diacunya. Jika mengamati tanda dan makna yang hadir dalam iklan Tokopedia versi BTS, akan tampak objek yang mengungkapkan sesuatu. Model tanda trikotomis atau triadik yang dikembangkan oleh Pierce, dituangkan secara sederhana melalui tiga titik yaitu representamen atau tanda, objek, dan interpretan. Ketika trikotomis tersebut dihubungkan dengan iklan Tokopedia versi BTS, maka dapat dilihat seperti gambar berikut:

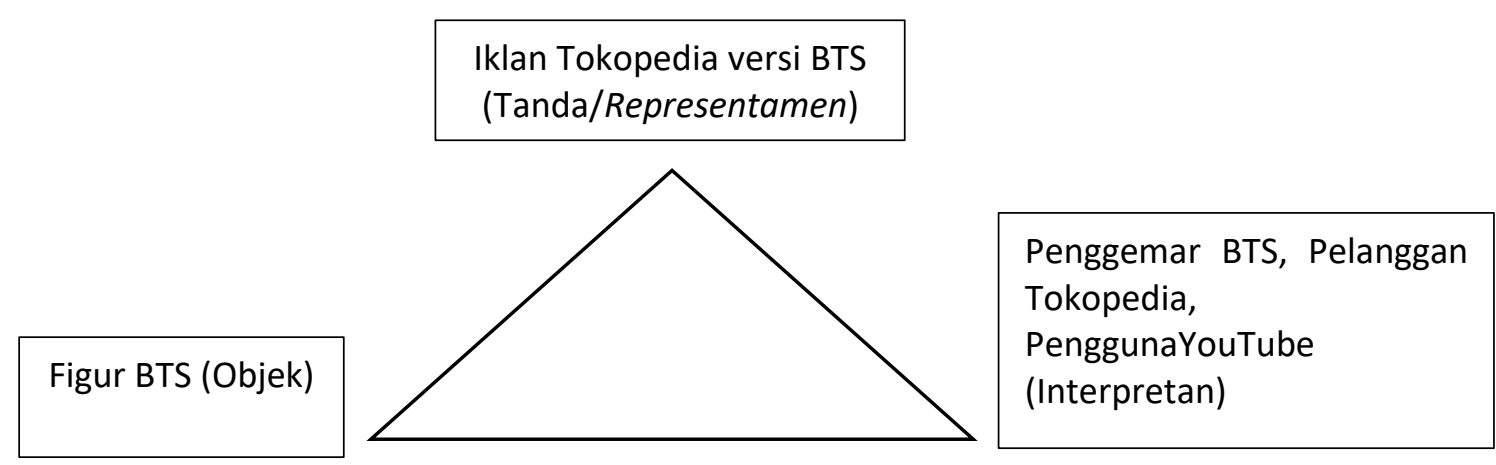

Gambar 1.8 Trikotomis Peirce terhadap iklan Tokopedia x BTS Sumber: Dokumen Pribadi, 2020

Tanda di sini adalah Iklan Tokopedia versi BTS yang memiliki enam versi di YouTube playlist Tokopedia x BTS, dengan objek bahwa personil BTS itu sebagai brand ambassador PT. 
Tokopedia. Sedangkan interpretannya adalah penggemar BTS, pengguna Tokopedia, dan pengguna Youtube.

\section{Identifikasi Tanda dalam Iklan}

Tahap pertama yang dilakukan sebelum menganalisis tanda adalah mengidentifikasikan tanda-tanda itu sendiri. Berdasarkan objeknya, Pierce membagi tanda atas icon (ikon), index (indeks), dan symbol (simbol). Dengan mengacu ketiga jenis tanda tersebut, dapat diidentifikasikan beberapa jenis tanda sebagai unit analisa yang diteliti. Identifikasi tanda dapat dilihat dalam tabel di bawah ini:

Tabel 2 Identifikasi Tanda pada Iklan Tokopedia x BTS di YouTube

\begin{tabular}{|c|c|c|}
\hline Jenis Tanda & Penjelasan & Identifikasi Tanda \\
\hline Ikon & $\begin{array}{l}\text { Tanda berhubungan dengan objek } \\
\text { karena adanya keserupaan. }\end{array}$ & $\begin{array}{l}\text { - Gambar BTS Full Team } \\
\text { - Gambar latar belakang } \\
\text { - Gambar tampilan makanan dan minuman, } \\
\text { peralatan rumah tangga, produk } \\
\text { kecantikan, fashion, top-up serta bayar } \\
\text { tagihan dan elektronik. } \\
\text { - Gambar potongan aktivitas memakai } \\
\text { produk sambil menari. }\end{array}$ \\
\hline Indeks & $\begin{array}{l}\text { Adanya kedekatan eksistensi antara } \\
\text { tanda dengan objek atau adanya } \\
\text { hubungan sebab akibat. }\end{array}$ & $\begin{array}{l}\text { - Pakaian yang dikenakan oleh BTS } \\
\text { - Tiporafi (jenis font) yang digunakan. } \\
\text { - produk yang ditawarkan }\end{array}$ \\
\hline Simbol & $\begin{array}{l}\text { Hubungan ini bersifat konvensional } \\
\text { dalam artian ada persetujuan } \\
\text { tertentu antara para pemakai } \\
\text { tanda. }\end{array}$ & $\begin{array}{l}\text { - Teks merek "Tokopedia” } \\
\text { - Teks tagline “Belanja? Tokopedia Saja” } \\
\text { - Teks headline (judul/tema) "Tokopedia x } \\
\text { BTS" } \\
\text { - Teks subheadline "Tokopedia Nomor } 1 \\
\text { Everyday" } \\
\text { - Teks bodycopy (isi iklan) “Bebas Ongkir" } \\
\text { - Teks mandatories “Buka Tokopedia Setiap } \\
\text { Hari! Download Tokopedia di App Store } \\
\text { dan Google Play" }\end{array}$ \\
\hline
\end{tabular}

Sumber: Dokumen Pribadi, 2020

BTS dalam hal ini menjadi representasi anak muda Korea Selatan yang bekerja keras, sukses dan relatif jauh dari skandal. Berikut ini adalah jabaran informasi tentang sifat-sifat anggota BTS yang diberikan berdasarkan situs Fakta.id: (1) Jimin mempunyai sifat kelucuan yang sering membuat anggota BTS lainnya tertawa. Walaupun lucu, Jimin tetap mempunyai karakter yang mempesona. Meski usianya lebih muda, namun Jimin dianggap punya kedewasaan yang baik, (2) J-Hope mempunyai tingkat rasa kasih sayang yang tinggi. Bila ada yang terlihat sedih, maka J-Hope merupakan orang yang akan menghiburnya. Ketika ada ketegangan, J-Hope juga akan menjadi pencair suasana, (3) Jin, sebagai anggota tertua, Jin mempunyai rasa kepemimpinan yang besar. Walau lebih dewasa, Jin tetap menjadi sosok yang asik untuk diajak berbicara. Jin juga terkenal dengan sifatnya yang ramah kepada siapa saja, (4) RM merupakan sosok yang sangat jenius diantara anggota lainnya. la juga dikenal sebagai orang yang mandiri. RM menjadi sosok pelindung yang akan menghormati siapapun di dekatnya, (5) Suga, Setara dengan RM, Suga juga dianggap sebagai sosok yang jenius. Suga mempunyai sifat yang lebih emosional dibanding anggota lain. Selain pintar, Suga juga menjadi sosok yang kreatif, (6) Kim TaeHyung (V) mempunyai sifat yang cukup nakal. Walau terkesan nakal, ternyata $V$ juga mempunyai sifat keibuan. $V$ juga terkenal sebagai sosok yang sangat ambisius, (7) Jungkook 
memiliki karakter yang mirip seperti Jin, pandai membuat orang tertawa dengan tingkahnya. Walau lucu, Jungkook dikenal sebagai anggota yang suka membuat onar. Meski terlihat menggemaskan, tapi Jungkook merupakan sosok yang pekerja keras.

Secara umum, citra yang mereka miliki positif di tengah penggemar dan masyarakat. Sebagai grup musik, mereka bukan hanya piawai dalam bernyanyi, tetapi juga menulis lirik lagu dan komposisi musik. Bahkan RM (pemimpin grup), memiliki IQ 148, sering tampil di berbagai stasiun TV Korea dan menunjukkan kepintarannya. Tidak hanya pandai, RM juga suka membaca buku dan sangat fasih berbaha Inggris. Lirik-lirik yang ditulisnya, terisnpirasi dari buku-buku yang ia baca.

BTS telah menjadi brand ambassador resmi Tokopedia. Kecocokan BTS sebagai brand ambassador didukung oleh pernyataan yang disampaikan dari CEO Tokopedia yaitu William Tanuwijaya bahwa BTS adalah grup yang mengubah industri musik, terlepas dari batasan dan hambatan sepanjang perjalanan mereka. Pihak Tokopedia sangat menghargai komitmen mereka dalam inovasi dan menyebarkan kepositifan, oleh karena itu ia setuju bahwa BTS adalah pasangan yang tepat bagi Tokopedia untuk berbagi nilai Tokopedia kepada dunia" (WowKeren 2019). BTS sebagai brand ambassador yang memiliki karakteristik kredibilitas yang dipercaya untuk anggotaikan informasi iklan yang objektif, memiliki karakteristik daya tarik yang menunjang untuk menarik minat konsumen, dan karakterisitik kharisma yang dipancarkan oleh BTS kepada calon konsumen akan mempengaruhi untuk membeli dengan menggunakan Tokopedia. BTS telah berhasil membentuk brand awareness Tokopedia melalui iklan di YouTube yang saat ini telah menjadi aplikasi urutan nomor satu yang paling sering digunakan oleh masyarakat Indonesia. Jenis iklan yang digunakan oleh Tokopedia merupakan iklan persuasif, iklan penguatan dan iklan pengingat, bertujuan untuk membeli produk dan meyakinkan yang telah membeli bahwa sudah melakukan pilihan yang tepat, kemudian akan melakukan pembelian ulang dengan jasa Tokopedia,

Gaya dalam penyampaian pesan iklan YouTube Tokopedia terdapat tiga unsur, yaitu gaya musical yang diambil dari album BTS yang berjudul Boy With Luv, ditambah dengan penyampaian pesan iklan menggunakan tampilan gaya animasi yang membuat iklan lebih menarik serta lebih mudah dipahami dengan gambar-gambar, dan penyampaian pesan dengan gaya hidup atau life style bertujuan untuk memecahkan permasalahan konsumen dalam kebutuhan sehari-sehari dengan menunjukan produk yang diiklankan.

Dalam penelitian ini, calon konsumen akan mengambil keputusan dalam pembelian berdasarkan AISAS. Konsumen yang telah melihat iklan akan menimbulkan ketertarikan, sehingga munculnya keinginan untuk mencari informasi dengan cara mengunggah aplikasi Tokopedia untuk mencari informasi melalui intenet dari apa yang dibutuhkan. Kemudian konsumen membuat penilaian dari barang tersebut, dan membuat sebuah keputusan untuk membeli. Setelah melakukan pembelian, konsumen akan memberikan rekomendasi kepada orang lain tentang produk yang dibelinya atau anggotaikan penilaian kepuasan berupa komentar pada aplikasi Tokopedia bahkan membagikan atau sharing ke media sosial lainnya.

BTS yang memiliki banyak penggemar telah membawa pengaruh terhadap perilaku konsumen dalam konsumerisme produk, dan meningkatkan transaksi melalui aplikasi Tokopedia. Selain karakter positif BTS secara individual maupun satu kelompok Boyband itu, dinobatkan sebagai duta merek (Brand Ambassador) yang dianggap bisa mewakili karakter citra brand Tokopedia, kemungkinan BTS dianggap akan menarik respon citra persona konsumen Tokopedia yang termaktub dalam penggemar BTS, pengguna Tokopedia dan pengguna Youtube sebagai khalayaknya.

Pengambilan keputusan dari khalayak merupakan dari kelas pekerja, mahasiswa atau pelajar dari kelompok ekonomi menengah ke atas. Sedangkan pada iklan tidak terlalu banyak pesan verbal yang diucapkan namun selalu ada kata "Tokopedia". Untuk pesan verbal tertulis, kata "Tokopedia" selalu nampak pada layar. Karakteristik Tokopedia dalam membangun 
awareness dengan cara penggunaan slogan "Belanja? Tokopedia Saja!" dan jingle khusus Tokopedia. Pesan verbal tersebut untuk menegaskan bahwa BTS menganjurkan sepenuhnya Tokopedia menjadi tempat untuk belanja online.

Iklan YouTube yang telah dibuat oleh Tokopedia x BTS memiliki berbagai macam versi, yaitu sebagai berikut:

1. "Tokopedia x BTS Full Anggota - Bebas Ongkir? Tokopedia Saja!"

2. "Tokopedia x Jin BTS - Bebas Ongkir? Tokopedia Saja!"

3. "Tokopedia x V BTS - Bebas Ongkir, Belanja Fashion, Tokopedia Saja!"

4. "Tokopedia x RM dan J-Hope - Bayar Tagihan dan Beli Voucher? Tokopedia Saja!"

5. "Tokopedia x Jung Kook dan Jimin BTS - Belanja Kebutuhan Kecantikan? Tokopedia Saja! Bebas Ongkir!"

6. "Tokopedia x Suga BTS - Tukar Tambah? Tokopedia Saja!"

Tabel 3 Deskripsi versi Iklan YouTube Tokopedia x BTS

\begin{tabular}{|c|c|c|c|c|}
\hline Versi Iklan & Durasi & Gambar & Video & Audio \\
\hline $\begin{array}{c}\text { Tokopedia } \\
\text { x } \\
\text { BTS } \\
\text { (Full } \\
\text { Anggota) }\end{array}$ & $\begin{array}{c}45 \\
\text { detik }\end{array}$ & & $\begin{array}{l}\text { BTS berjalan } \\
\text { membelakangi } \\
\text { penonton. } \\
\text { Kemudian, } \\
\text { berhenti dan } \\
\text { membalikkan } \\
\text { tubuh ke } \\
\text { belakang. }\end{array}$ & $\begin{array}{l}\text { Musik: Opening lagu "DNA" } \\
\text { BTS: Halo Indonesia, } \\
\text { This is BTS! } \\
\text { RM: Saya RM } \\
\text { V: Saya V } \\
\text { j-hope: Saya j-hope } \\
\text { Jimin: Saya Jimin } \\
\text { Jin: Saya Jin } \\
\text { Suga: Saya Suga } \\
\text { JK: Saya JungKook } \\
\text { FVO: Bebas Ongkir? } \\
\text { BTS: Tokopedia Saja! Nomor } \\
\text { 1 Everyday } \\
\text { Tokopedia! Wuoh! } \\
\text { Tokopedia! }\end{array}$ \\
\hline
\end{tabular}




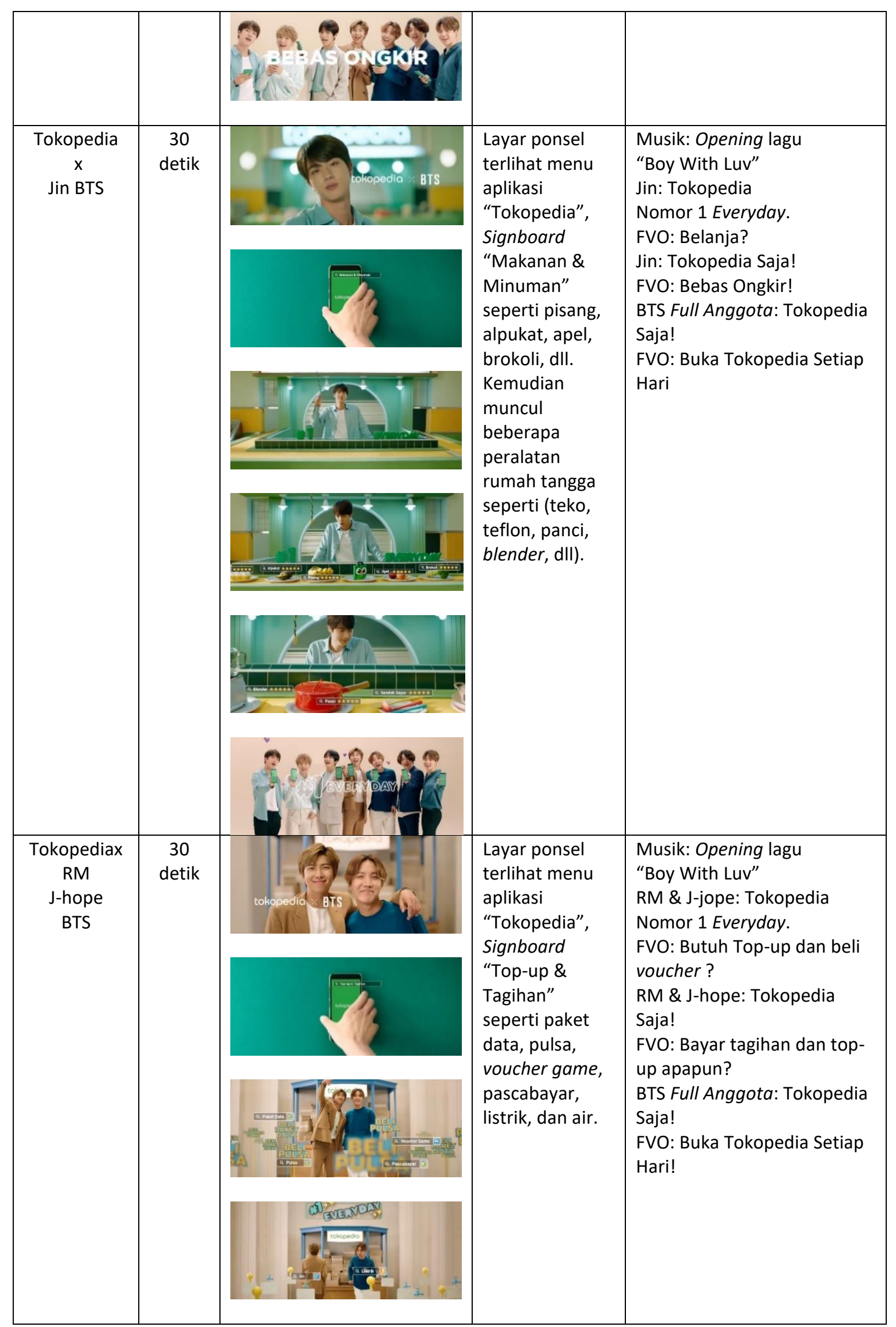




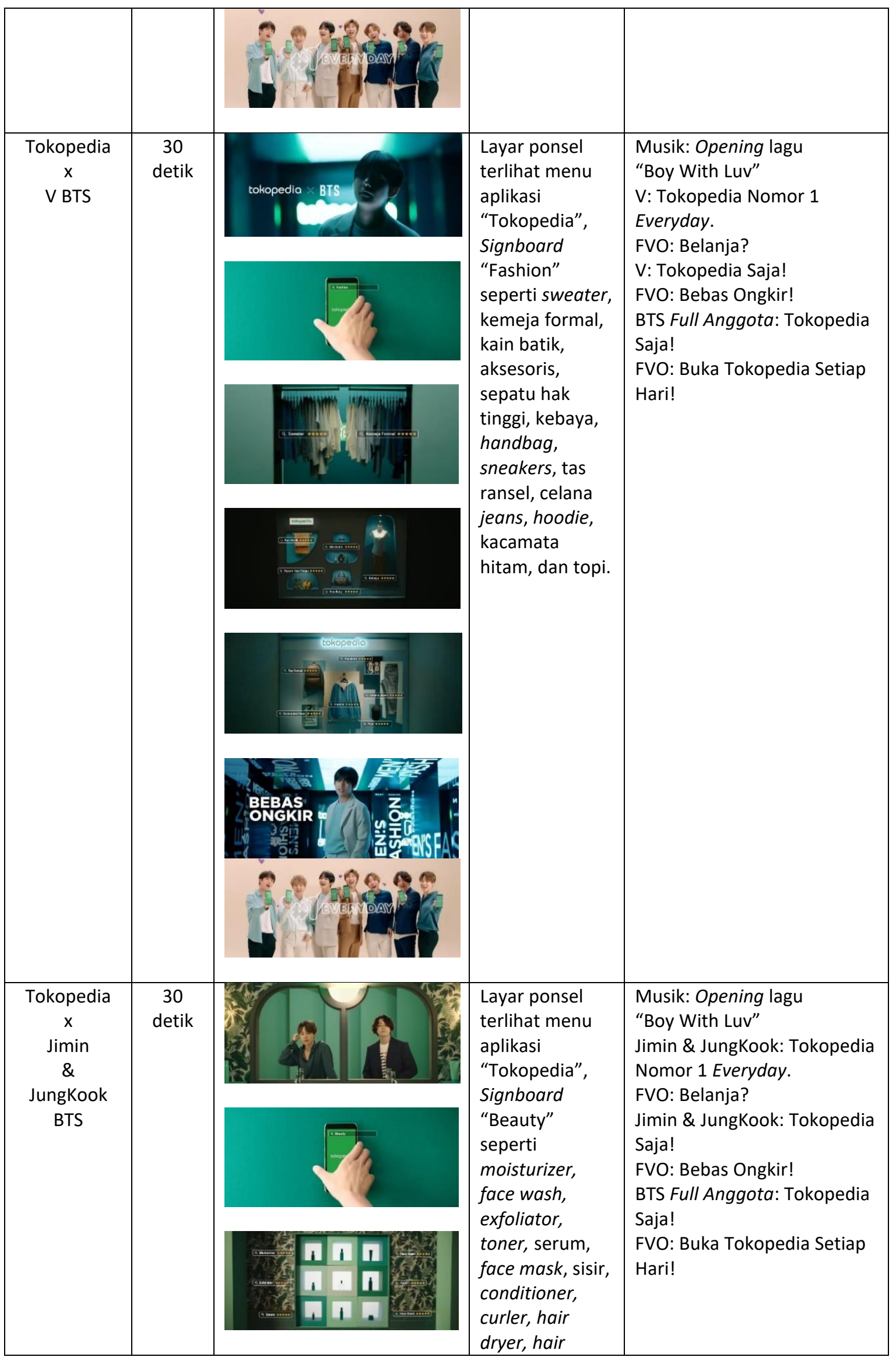




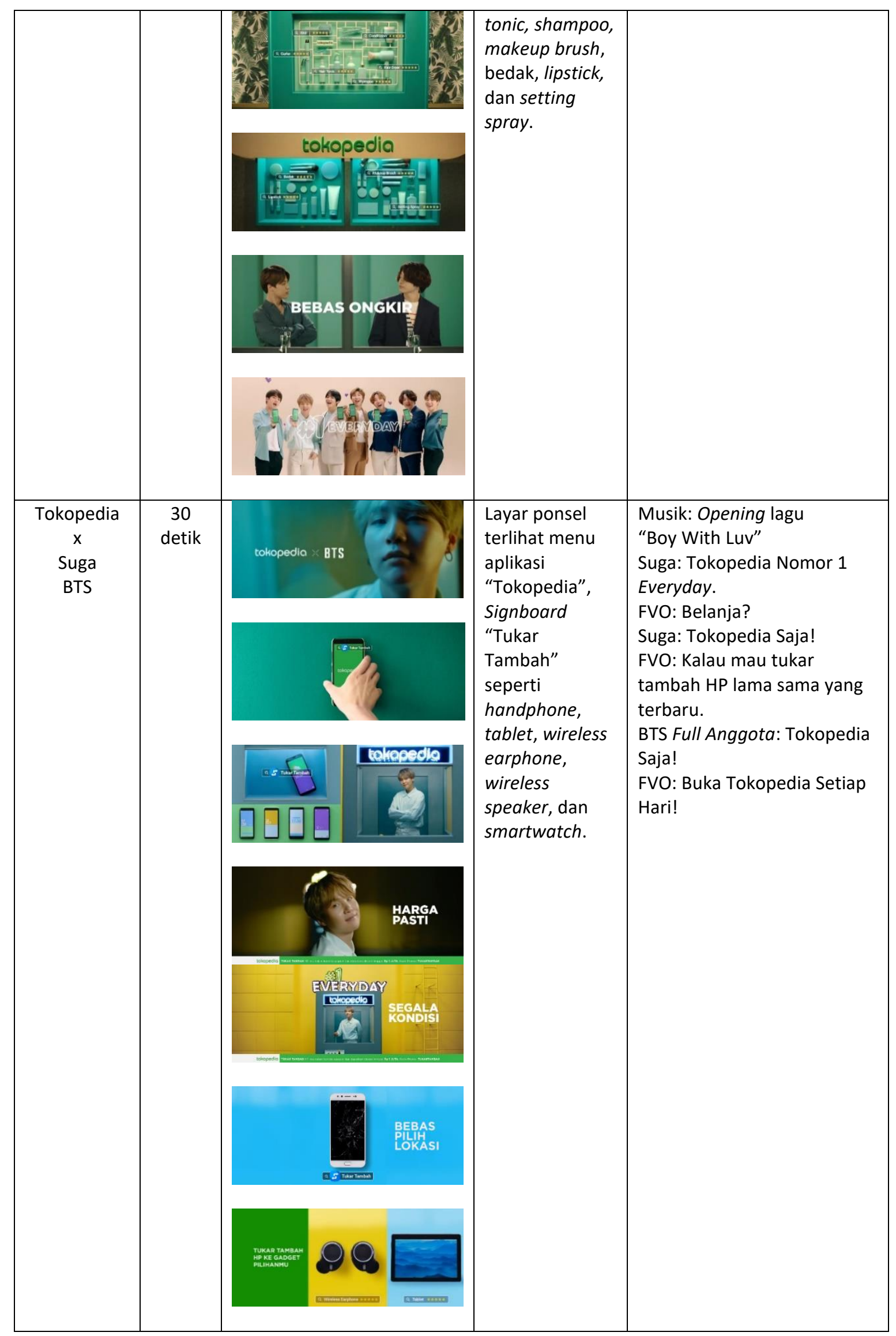




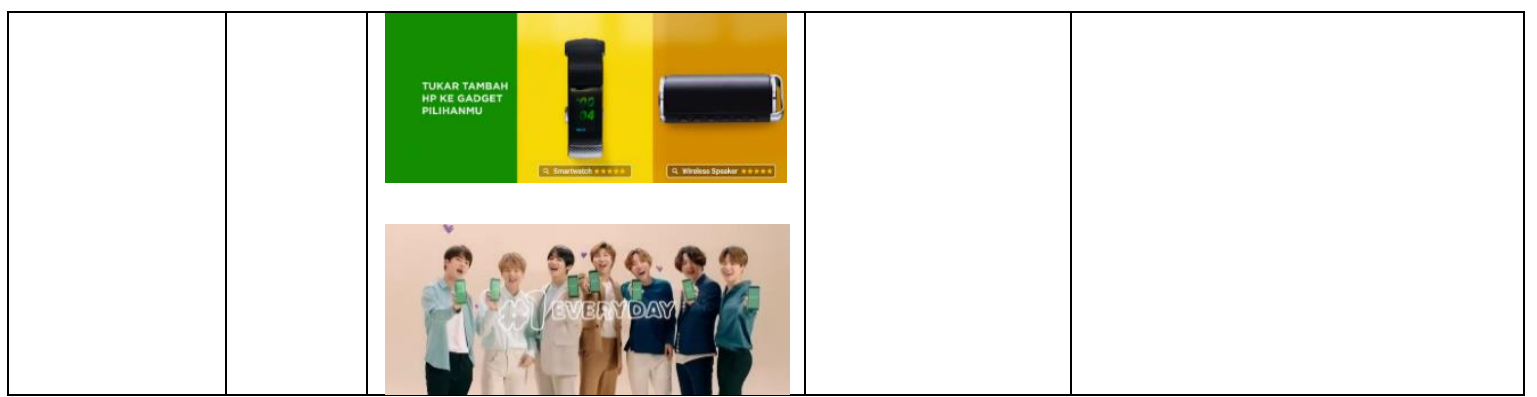

Sumber: YouTube Tokopedia x BTS. (Playlist Video Tokopedia x BTS”. Accessed July 20, 2020.)

Pada konten video di atas yang dilakukan oleh BTS di berbagai macam versinya terdapat tiga segmen, yaitu pada bagian pembuka, isi pesan iklan, dan penutup yang akan diuraikan di bawah ini:

1. Pembuka

Saat pembuka iklan pada detik ke 1 sampai 15 detik akan diawali dengan musik opening dari album BTS yang disertai dengan munculnya masing-masing dari personil BTS dengan beberapa ornamen desain animasi yang disesuaikan dengan versi judul iklan YouTube yang telah dibuat oleh pihak Tokopedia.

2. Isi Pesan Iklan

Isi pesan iklan akan disampaikan rata-rata dari setiap versi iklan pada detik ke 16 sampai 26 detik yang akan disebutkan oleh FVO atau ditampilkan pada gambar-gambar produk sesuai dengan versi judul iklan YouTube yang telah dibuat oleh pihak Tokopedia.

3. Penutup

Pada bagian penutup dari setiap versi iklan yang rata-rata berada pada detik ke 27 sampai 30 detik akan diakhiri iklan oleh FVO dengan kalimat "Buka Tokopedia Setiap Hari" dan jingle Tokopedia.

\section{Simpulan}

Penggemar BTS, pengguna Tokopedia dan pengguna Youtube dianggap sebagai pelanggan ideal yang harus membeli layanan/ produk yang diberikan adalah pokok dari setiap strategi pemasaran Tokopedia. Definisi persona pembeli adalah salah satu langkah penting pertama untuk membuat keputusan dan investasi bisnis, produk, dan pemasaran yang lebih baik. Tokopedia sebagai brand mengadopsi pendekatan berbasis data untuk membuat profil persona pembeli untuk menerapkan praktik pemasaran yang lebih strategis dan bertarget melalui citra BTS sebagai Brand Ambassador dan dalam arus Korean Waves.

Berdasarkan pembahasan mengenai tujuan penelitian ini yaitu tentang Iklan Tokopedia versi BTS Sebagai representasi Korean Waves telah dijabarkan berdasarkan data-data yang telah diperoleh, maka dapat disimpulan bahwa pada iklan Tokopedia, BTS yang menjadi brand ambassador telah menghasilkan citra visual bintang Korea dalam pandangan umum budaya di Indonesia. Citra yang dituangkan dalam bentuk iklan, merupakan perpaduan dari elemen desain (warna, garis, tata letak, dan sebagainya) dan elemen film (narasi dan teknik pengambilan gambar). Dimana di dalamnya, pemilihan tata rias, busana, grafis, teks, teknik editing, audio menjadi satu kesatuan sehingga membentuk kesan karakter yang dimaknai oleh penggemar BTS, pengguna Tokopedia, dan pengguna Youtube secara umum ikut dalam Korean Waves. Tampilan grafis yang sederhana, dengan menggunakan warna-warna pastel, dan gaya editing video, 
memang sudah ditujukan untuk tampilan media baru yaitu YouTube, yang penuh dengan sparkling dan animasi yang manis yang disesuaikan dengan karakter target khalayak Tokopedia.

Dalam upaya mempertahankan posisi teratas Tokopedia pada pasar e-commerce, Tokopedia berkolaborasi dengan BTS berharap dapat mendorong masyarakat untuk selalu berjuang dan melakukan yang terbaik setiap hari bersama Tokopedia dan juga untuk menjangkau pasar remaja muda khususnya penggemar artis Korea atau disebut sebagai $K$ popers di antaranya yaitu para wanita, pekerja, pelajar atau mahasiswa dari kalangan ekonomi menengah ke atas.

Hasil dari penelitian ini menunjukkan bahwa citra positif yang dimiliki BTS yang menjadi representasi anak muda Korea Selatan, yang bekerja keras, sukses dan relatif jauh dari skandal telah berhasil membangun brand awareness Tokopedia di hadapan khalayak. Dengan adanya kolaborasi di antara Tokopedia dan BTS, maka hasil dari kerjasama yang terjalin di antara mereka sangat membawa hal baik bagi keduanya, yaitu bagi perusahaan Tokopedia dan bagi BTS.

\section{Daftar Pustaka}

Arikunto, Suharsimi. 2016. Prosedur Penelitian: Suatu Pendekatan Praktik suharsimi. Jakarta: Rineka Cipta.

Databoks. 2018. "Tokopedia Tetap Memimpin Jumlah Pengunjung e-Commerce TW III 2018." $\begin{array}{lllll}\text { kata data. } & \text { Accessed } & 6 & \text { Juli }\end{array}$ https://databoks.katadata.co.id/datapublish/2018/10/22/tokopedia-tetap-memimpinjumlah-pengunjung-e-commerce-tw-iii-2018.

Gultom, Shelma Bertari, and Devilia Sari. 2019. "Pengaruh Brand Ambassador Blackpink Terhadap Brand Image E-commerce Shopee." eProceedings of Management 6 (2): 40474053.

https://openlibrarypublications.telkomuniversity.ac.id/index.php/management/article /view/9447.

Herdadi, Farah. 2019. Pengembangan Sistem Informasi Farah Aprilia Herdani. Accessed 10/21.

ibighit. "Profile BTS." Big Hit Entertainment. Accessed 6 Agustus 2020. https://ibighit.com/bts/eng/profile/.

Jayani, Dwi Hadya. 2020. "10 Media Sosial yang Paling Sering Digunakan di Indonesia." katadata. Accessed 6 Juli 2020. https://databoks.katadata.co.id/datapublish/2020/02/26/10media-sosial-yang-paling-sering-digunakan-di-indonesia.

Jeong, Jae-Seon, Seul-Hi Lee, and Sang-Gil Lee. 2017. "Korean Wave| When Indonesians Routinely Consume Korean Pop Culture: Revisiting Jakartan Fans of Korean Drama Dae Jang Geum." International Journal of Communication 11: 2288-2307. https://ijoc.org/index.php/ijoc/article/view/6302.

Kriyantono, Rachmat. 2006. Teknik Praktis Riset Komunikasi: Disertai Contoh Praktis Riset Media, Public Relations, Advertising, Komunikasi Organisasi, Komunikasi Pemasaran. Jakarta: Kencana Prenada Media. 
Lee, Yu Lim, Minji Jung, Robert Jeyakumar Nathan, and Jae-Eun Chung. 2020. "Cross-National Study on the Perception of the Korean Wave and Cultural Hybridity in Indonesia and Malaysia Using Discourse on Social Media." Sustainability 12 (15): 6072. https://www.mdpi.com/2071-1050/12/15/6072.

Moleong, Lexy J. 2018. Metodologi Penelitian Kualitatif. Bandung: PT Remaja Rosdakarya.

Onlenpedia. 2015. "Kisah Perjalanan Tokopedia." Accessed 15 Juli 2020. https://www.onlenpedia.com/2015/10/kisah-perjalanan-tokopedia-versi.html.

Sobur, Alex. 2006. Analisis Teks Media: Suatu Pengantar Untuk Analisis Wacana, Analisis Semiotika, dan Analisis Framing. 4th ed. Bandung: PT Remaja Rosdakarya.

Tina, Limar, and Lusia Savitri Setyo Utami. 2020. "Formation of Tokopedia Image Perceptions in Public (Study On BTS Fans, ARMY)." The 2nd Tarumanagara International Conference on the Applications of Social Sciences and Humanities (TICASH 2020), 2020-1211T22:39:45.000Z.

Tjoe, Fandy Zenas, and Kyung-Tae Kim. 2016. "The Effect of Korean Wave on Consumer's Purchase Intention of Korean Cosmetic Products in Indonesia." The Journal of Distribution Science 14 (9): 65-72. https://doi.org/10.15722/jds.14.9.201609.65.

Tokopedia. "Kisah Kami." Tokopedia. Accessed 15 Juli 2020. https://www.tokopedia.com/about/our-story.

---. "Tokopedia X BTS." https://www.youtube.com/playlist?list=PLmmGB6SXc 3QEYaErBQhwluHHCMrKO7R.

---. 2015. "Menjawab pertanyaan "Kenapa Maskot Toped itu burung hantu dan kantong belanja?"." 11 Oktober 2015. https://web.facebook.com/tokopedia/photos/menjawabpertanyaan-kenapa-maskot-toped-itu-burung-hantu-dan-kantongbelanjamask/10153715976504612/? rdc=1\& rdr.

---. 2021. "Biodata Member BTS Lengkap \& 10 Fakta Menarik Personelnya." https://www.tokopedia.com/blog/profil-biodata-fakta-personel-bts/.

TribunWiki. 2019. "Tokopedia Jadi Aplikasi Terbaik Android dan IOS." Tribun News, 2019. Accessed 15 Juli 2020. https://makassar.tribunnews.com/2019/02/17/tribunwikitokopedia-jadi-aplikasi-terbaik-android-dan-ios-ini-sejarah-dan-pendirinya?page=all.

WowKeren. 2019. "Tokopedia Resmi Umumkan BTS Sebagai Brand Ambassador dan Rilis Video Iklan Baru." Wow Keren. Accessed 6 Agustus 2020. https://www.wowkeren.com/berita/tampil/00276973.html. 